\title{
Dette er en god tittel
}

I reklamebransjen heter det at en annonse må fange leserens oppmerksomhet innen ett sekund. Har dette relevans for forskningspublisering? Mer enn du kanskje tror, og mer enn mange forskere liker å tro.

Forskning har liten verdi hvis ikke resultatene når frem til andre. Pasientbehandlingen og forståelsen av biologiske og sosiale fenomener påvirkes av ny forskning bare hvis resultatene og analysene blir lagt merke til. Et forskningsprosjekt er ikke ferdig før forskningsartikkelen er publisert og lest, forstått og trodd på av andre. Godt språk, illustrerende figurer og oversiktlige tabeller bidrar til at forfatterens budskap når frem til leserne $(1,2)$. Like viktig er det at artikkelens overskrift - tittelen - er utformet slik at den tiltrekker lesere - på samme måte som reklamen tiltrekker forbrukere.

Hva er så en god tittel på en vitenskapelig artikkel? En erfaren skribent og redaktør har uttrykt det slik: En god tittel er det som redaktøren av det aktuelle tidsskriftet mener er en god tittel (3). Utsagnet har mye for seg. Vurderingen av en tittels kvalitet er i stor grad subjektiv, og ulike tidsskrifter har ulike regler og ulik praksis når det gjelder utforming. Mange tidsskrifter, bl.a. The New England Journal of Medicine, aksepterer ikke konklusive titler, dvs. titler der studiens konklusjon fremgår, noe som - dessverre - synes å bli vanligere innen enkelte fagområder (4). Slike titler gir inntrykk av en generaliserbarhet av funnene som det sjelden er dekning for (5). I Tidsskriftet stiller vi ikke krav om at studiens design skal fremgå av tittelen, slik mange tidsskriftet krever. Vi bruker heller ikke undertitler, slik enkelte tidsskrifter gjør. Forfatterveiledningen på nett inneholder for øvrig ingen råd om tittelutforming (6).

Den beste definisjonen jeg har funnet på en god tittel er denne: En tittel som med færrest mulig ord dekker artikkelens innhold på en adekvat måte (7). Korte titler, men ikke for korte, er oftest å foretrekke fremfor lange. Tittelen må vekke interesse og være såpass presis at den vil bli identifisert ved et systematisk litteratursøk i elektroniske publiseringsdatabaser senere. En redaktør med tilknytning til $B M J$, et av verdens ledende medisinske tidsskrifter, har listet opp sine krav til en god tittel: konsis og presis, informativ og beskrivende, spesifikk (dvs. med studiedesign), ikke misvisende, representativ for klassifiseringen og interessevekkende (8).

Tittelen er altså viktig, og forfattere bør legge mye arbeid i å få til gode titler. En vanlig feil er at man presser for mye informasjon og for mange og for lange ord inn i tittelen - dette gjelder særlig forfattere av originalartikler. Bruk heller korte ord til erstatning for lange der dette er mulig, bruk færre ord og la helst de viktigste ordene stå langt fremme. En god tommelfingerregel er at tittelen må være sann, men at den ikke trenger å være helt presis.

Hvis første utkast til tittel er altfor langt, kan det være en god idé å sette opp en prioritert liste over ordene i tittelen og deretter skrive en ny der bare (eller nesten bare) de høyest prioriterte er med. Slike titler blir ofte mindre presise, men bedre - uten å være misvisende. En tittel som Levealder og dødsårsaker etter enkelte resultater $a v$ helsekontroll hos bedriftslege: 40 års oppfølging av menn i femtiårene som deltok $i$ Oljeforsøket 1964-65 (157 tegn) kan på den måten forkortes til Levealder og dødsårsaker hos menn undersøkt ved helsekontroll $i 1964$ (68 tegn) for en artikkel som fortjener å bli lest (9).

Titler til oversiktsartikler er ofte lettere å lage. Også her må konklusive utsagn unngås. For begge artikkeltyper er det viktig at tittelen formidler troverdighet og seriøsitet - moteord, floskler og tabloide uttrykk bør derfor ikke brukes $(5,10)$. Forkortelser blir vanligvis ikke akseptert, heller ikke i Tidsskriftet. De fleste av våre forfattere uttrykker takknemlighet for hjelp fra redaksjonen til å få laget en bedre tittel.

Kriteriene for en god tittel er annerledes for kronikker, kommentarartikler og lederartikler enn for originalartikler og oversiktsartikler. Tittelen til slike artikler $m a ̊$ være kort. Lange og kompliserte ord bør unngås. Budskapet kan gjerne komme frem i spisset, komprimert form. Forfatteren kan formulere seg både konklusivt, tabloid, upresist og kryptisk (innen visse grenser) for å få folk til å lese videre. Hvis du har lest helt hit, har jeg denne gang lyktes godt.

Jeg takker forfatterne for tillatelse til å nevne deres artikkel (9).

\footnotetext{
Litteratur

1. Gjersvik P. Språket er en del av faget. Tidsskr Nor Legeforen 2012: 132: 613 .

2. Lunde S. Mer enn tusen ord. Tidsskr Nor Legeforen 2012; 132: 924-5.

3. Albert T. A-Z of medical writing. London: BMJ Books, 2000.

4. Langdon-Neuner E. Titles in medical articles: what do we know about them? The Write Stuff 2007; 16: 158-60.

5. Nylenna M. Publisere \& presentere. Medisinsk fagformidling i teori og praksis. Oslo: Gyldendal Akademisk, 2008.

6. Forfatterveiledning for Tidsskriftet. www.tidsskriftet.no/index.php/Innhold/ Forfatterveiledningen (2.1.2013).

7. Day RA, Gastel B. How to write and publish a scientific paper. 6. utg. Cambridge: Cambridge University Press, 2006.

8. Moss F. Titles, abstracts, and authors. I: Hall GM, red. How to write a paper. 4. utg. London: BMJ Publishing Group, 2008

9. Bjerkedal T, Kristensen P. Selmer K. Levealder og dødsårsaker hos menn undersøkt ved helsekontroll i 1964. Tidsskr Nor Legeforen 2012; 132: $30-5$.

10. Hem E. Styr unna moteordene. Tidsskr Nor Legeforen 2012; 132: 1128-9.
} 